\title{
Web検索サービスの法的諸問題
}

\section{Legal issues of web search service}

\author{
高田 寛 ${ }^{1,2,3}$
}

\section{TAKADA Hiroshi ${ }^{1,2,3}$}

1 株式会社ビーコンインフォメーションテクノロジー（テ160-0023 東京都新宿区西新宿1-24-1) Tel : 03-3340-2461

2 国土舘大学法学部

3 産業能率大学情報マネジメント学部

1 Beacon Information Technology Inc. (1-24-1 Nishishinjuku Shinjuku-ku, Tokyo 160-0023)

2 Kokushikan University

3 Sangyo-Noritsu University

原稿受理（2009-06-09）

（情報管理５2(5), 267-275)

\section{著者抄録}

近時, Googleは, 従来の検索エンジンによるサービスのほかに, Googleブック検索やGoogleストリートビューなどの新 しいサービスを提供し, 社会的にも大きな影響を与え始めている。しかし, これらの新サービスには法的に未解決の 部分も多い。本稿では, 近時のGoogleのサービスの最新動向とともに, 過去の重要判例を交えながら, これら検索サー ビスに関連する法的問題を整理し，今後の潜在的な法律上の問題を考えてみたい。

キーワード

検索サービス, 検索エンジン, Googleブック検索, Googleストリートビュー, フェアユース, 孤児作品, 集団訴訟, オプト アウト方式

1.はじめに

法と技術の関係は，一般に，法が技術の後追いを するという傾向がある。技術の進展が早く社会に影 響を及ぼすようになると，既存の法では解決できな い問題が社会問題として顕在化する。また，新技術 を用いたサービスのグローバル化によって，まった く予想していなかった外国での訴訟の結果が, 個人 の問題として目前に突きつけられることもある。 Web検索サービスの世界もその例外ではない1)。 Web検索サービスの世界市場は, 最大手のGoogle
が約7割を占め, それに続きYahoo!, 中国の百度, Microsoftその他の検索サービス事業者が占めている 状態にある。検索サービス市場は, 世界規模で, 現 在では約270億ドルとも言われ巨大な市場を形成し ている。

このように検索サービスの世界に君臨するGoogle であるが, 従来の検索エンジンによる検索サービス だけでなく, Googleブック検索 (Google Book Search) のように，世界中の書籍を検索できるシステムを構 築し，利用者に提供できる新しい検索サービスや， Googleストリートビュー (Google Street View) のよ 
うにGoogle Map上に街路（公道）から見た360度パ ノラマの風景画像の表示サービスを展開している。

このような革新的とも言える新しいGoogleの検索 サービス事業は，大きな社会的影響をもたらし実社 会に変革を与えようとしている。しかし，これら 新しいGoogleのサービスは社会的影響が大きいだけ に，至るところで波紋を呼び物議をかもしているの も事実である。

例えば，2008年暮れ，3年間続いた世界中の書籍 について全文検索ができるというGoogleブック検索 に関する集団訴訟 (class action) が和解した。しかし, この訴訟は集団訴訟であるため，わが国の権利者に も大きな影響を与えている状況にある。

また, Googleストリートビューでは, 街路を歩く 人物や住宅地の画像までが公開されているが，これ らの画像は関係者から事前に許諾を得て公開したも のではない。そのため, このサービスそのものがプ ライバシーの侵害や個人情報に関する問題があるの ではないかという指摘がなされている。

本稿では, 近時のGoogleのサービスの紹介ととも に，過去の重要判例を交えながら，これらGoogleの 検索サービスに関連する法的問題を整理し，潜在的 な法律上の課題を考えてみたい。

\section{2. 検索サービスの最新動向}

\subsection{Googleブック検索}

2008年10月28日，世界中の書籍について全文対 象検索を目的亡するGoogleブック検索に関する集団 訴訟が，二ューヨーク州南部地区地方裁判所で和解 した2)。

Googleブック検索とは，検索画面上にキーワード を入れると，そのキーワードを含むすべての書籍が 検索できるものである。保護期間が切れていたり， 必要な許諾を受けている書籍ならば全文表示が可能 となる。そうでない書籍については，書誌情報やス 二ペット(数行の抜粋) が表示される。このように,
世界中の書籍が検索でき全文が読めるようにすると いう壮大な計画である。

Googleブック検索は, 出版社や著作者亡契約を交 わして書籍を公開する「パートナープログラム」と， 図書館から無償提供された蔵書をデータベース化し て公開する「図書館プロジェクト」の2つのプロジェ クトからなる。主に問題となるのが，「図書館プロ ジェクト」である。

Googleは2004年から, 米国内で八ーバード大学な ど主要大学と提携して蔵書のデジタル化を進めてい るが,「図書館プロジェクト」では, 直接, 出版社 や著作権者から利用許諾を受けてない。そのため, 図書館の蔵書をスキャンしてデータベース化するこ とが著作権侵害に当たるのではないかという懸念の 声が上がった。

2005年9月20日, 米国作家協会 (The Authors Guild) と米国出版社協会 (Association of American Publishers）は，著作権者の許諾を得ないで書籍をス キャンする行為はビジネス目的の複製であり著作権 法違反であるとして, Googleを相手どり提訴した。 一方, Googleは著作権法で認められているフェア ユース（公正な利用）（17 U.S.C. § 107）の範囲内 であり著作権法違反には当たらないと主張した3)。

この訴訟は，3年間争われていたが，2008年10月 28日，原告である米国作家協会および米国出版社協 会は，被告であるGoogleと和解合意に達した。

問題は，この訴訟が集団訴訟として提起されてい たことである。集団訴訟とは原告が利害を同じにす る者の集団の代表として訴訟を行うもので, 訴訟結 果は利害関係人全体に及ぶ。もともと，集団訴訟は 公害問題や製造物責任などに適用され，訴訟結果を 利害関係人全体に及ぶことを救済の目的とされたも のである。よって, 今回のGoogleブック検索の和解 合意も, 米国作家協会や米国出版社協会と同じ利害 に立つ一般の著作権者全体にも及ぶことになる。

すなわち, わが国の作家, 漫画家など書籍の著作 権者はすべて含まれることになり，この和解案に不 
合意の意思表示をし, 和解案から離脱しなければ, 裁判所の承認が条件であるものの, 自動的に和解条 件に拘束されることになる。

和解対象は，2009年1月5日以前に出版または頒 布された書籍や挿入物であり, 米国内での出版に限 定されない。すなわち，わが国を含む世界中のほと んどの国の書籍が対象となる。

和解内容の大きなポイントは, 米国内で著作権が 保護された書籍でも，絶版本か市販されていない書 籍ならばデジタル化して商業利用ができるようにな り，その見返りとして，これによってGoogleの得た 売上（revenue）の63\%が権利者に支払われ，権利 者の特定と分配のために「版権レジストリ」と呼ば れる非営利法人が設立されることである。また，許 可なくデジタル化された書籍（2009年9月4日以前 にスキャンされた作品）については，解決一時金と して, メイン作品 (principal work) あたり60ドル以上, 挿入物は5ドル／15ドル以上の金額を権利者が受け 取ることができる。しかし，2009年9月5日以降に スキャンされる作品にはこの解決一時金はない。

和解合意の背景には, Googleの権利者に対する巨 額の分配金がある。特に絶版となっている作品は中 古書籍として古本屋で取引されるほか，書店で販売 されることはなく，そのため著作権者に著作権使用 料が支払われるわけでもない。

しかし, Googleブック検索で検索されると収益の 一部が絶版となった書籍の権利者にも配布されると いう権利者のメリットがある。

和解案は米国が対象であり，書籍の閲覧は当面米 国内からのアクセスに限られるものの, 和解案の影 響はわが国にも及ぶ。2009年2月24日，わが国の各 新聞紙にGoogleからの「法定通知」が掲載された。 これにより，わが国の著作権者は米国の図書館に蔵 書があるかどうかを調べ，9月4日（当初は5月5日 までだったものが延長された）までに和解の諾否を しなければならない。

しかしながら，この和解案の拒否を表明している
権利者もある。書籍のデジタル化は, 今後避けて通 れない流れであることは承知しているものの, 今回 のGoogleのやり方に対して不満の声も上がっており 拒否を表明した団体もある。

例えば，2009年4月27日，日本ビジュアル著作権 協会会員の178人は，この和解案を拒否した。また， 2009年5月21日, 中小の出版社約100社で組織する 出版流通対策協議会 (流対協) も和解案を拒否する ことを発表した。しかし，和解案拒否から一転して 賛成した団体もある。日本文芸家協会は，2009年4 月15日, 日本の著作権者と出版各社を大混乱に巻き 込んだとする抗議声明をGoogleに対し表明したが, その後, 抗議声明を撤回した。

Googleブック検索訴訟の和解案から離脱すること は可能である。しかし, 現実問題として, その選択 肢を取る可能性は少ないであろう。なぜなら, 和解 案から離脱すれば, 過去のスキャンに対する解決一 時金（60ドル）が受け取れないし，またGoogleのス キャンやスニペット表示を止めることもできないか らである。もし止めようとすれば, Googleや図書館 に対し訴訟を提起しなければならない。いつたんは 和解に応じ，その後Googleに対して「表示使用」を 止めさせる方が得策であると考えられる。

この和解案の最終審理は, 2009年10月7日に ニューヨーク南部地区地方裁判所で行われるが，こ の和解案は米国反トラスト法（米国独占禁止法）に 違反する可能性があるとして, 米国司法省が調査を 開始している。

この調査対象は,「孤児作品 (orphan works)」の デジタル化である。和解案はGooglelのみこれを認 めている。全書籍のうちパブリック・ドメインにあ るものが約20\%，その他の書籍は，著作権者がはっ きりしているものは一部であり，70～75\%は著作 権者がはっきりしていない孤児作品である。孤児作 品には権利者がいない。Googleにこれを認めれば, Googleは巨大な孤児作品市場を独占的に開拓できる のである4)。 
また，和解案のGoogleに他の企業と同等の優遇措 置を保証するというGooglel対する最恵国待遇条項 とも言うべきものも反競争的であると考えられる。 なぜなら，他の業者が「版権レジストリ」の書籍を 利用したい場合, Googleよりも有利な条件を受けら れないからである。

いずれにせよ，10月7日の裁判所の最終承認を待 たなければならないが，米国における訴訟が集団訴 訟である以上，わが国の権利者にも多大な影響を与 える結果となる。これはまさに米国の訴訟システム である集団訴訟が，世界的に大きな影響を与えるこ とになり，いわば訴訟のグローバル化が進んでいる と言っても過言ではないであろう。これを期に，わ が国でも書籍のデジタル化に対する議論が活発にな ることが予想される。

\subsection{Googleストリートビュー}

Googleストリートビューは, 地図表示機能であ る「Googleマップ」の新機能のひとつであり, 公道 から360度パノラマカメラで撮影した主要都市の街 路の詳細な画像情報をネットから閲覧できるという Googleの無料サービスである。自分が道路に立って いる状態で周りの風景を全方位表示でき, 道路沿い の風景を静止画像で眺めることができる。

わが国では, 米国から1年遅れて2008年8月5日に 公開された。利用できる地域は, 札幌, 小樽, 函館, 仙台, 東京, さいたま, 千葉, 横浜, 鎌倉, 京都, 大阪，神戸の12都市で，Googleは，今後サービスの 拡大を目指している。

ストリートビューのサービスは高い利便性を持つ ものである一方で，住民の中には，自分の知らない うちに自宅や生活状況の画像が世界中に公開される ことについての不快感や抵抗感，あるいは戸惑いが 生じ, さらに防犯上の懸念の声も上がっている。

実際に，東京都町田市の「地域安全に関する意見 書」, 東京都杉並区のGoogleに対する申し入れ，衆 議院総務委員会での質疑, 東京都情報公開・個人情
報保護審議会, 弁護士会などで, ストリートビュー の風景画像が, そこの住人のプライバシーや肖像権 を侵害しているのではないか，または，これらの風 景画像が個人情報に該当するのではないか, さらに, ストリートビューが犯罪に悪用され, 地域の安全に 影響を与えるのではないかという問題が指摘されて いる。

Googleのストリートビューに表示される画像の中 には, 公開に適さないものが含まれている可能性が あるため, Googlel, 不適切, 慎重に扱うべきと思 われる画像を, 利用者が簡単に報告できるツールを 提供している。

実際に，路上での男女の高校生同士のキスシーン が撮影され，一時ストリートビュー上に公開された が，好ましくない画像として報告されGooglelまそれ を削除した。しかしながら，いつたん公開されたこ の画像は，興味本位のサイトに無断複製され，依然 として別のサイトで公開されているという事例も報 告されており, このように不適切な画像の報告によ る削除だけでは，十分な対応ができていないのが現 状である。

偶発的に撮影された個人の顔や表札，自動車のナ ンバープレート，キスや抱き合う男女の姿など，ぼ かしが入らないで明瞭に判別できる画像として公開 された場合，これがプライバシーの侵害にあたるか どうかが主な問題となるが, 顔などにぼかしを入れ た場合でも，年恰好や服装から，地域住民が個人を 特定できる可能性が高い場合, プライバシーの侵害 となり得るかが問題となる。

わが国では, プライバシーを保護する特定の法令 は存在しないが，一般に憲法第13条の幸福追求権に 法的な解釈の基礎を置くと考えられている。プライ バシーとは，みだりに私生活を他人に見られたくな いという人の不快感を基礎とする人格権であり, 基 本的に個々の人の持つ固有の感性に左右されるもの である。近時, 情報コントロール権説が有力である が，ストリートビューで問題となる画像に関して， 
プライバシー固有情報は当然のことながら，プライ バシー外延情報としてコントロールされる権利の侵 害があるかどうかが問われることになり，その範囲 の基準をどこに置くかが議論すべき問題である。

その有力な手がかりを考えるならば，それは平穏 のプライバシー権説であろう。これは，外部の刺激 から心の平穏を守ることをプライバシーに含める見 解であり, 最高裁の伊藤正己裁判官は, 最高裁判決 の少数意見として，「現代社会において，他者から 自己の欲しない刺激によって心を乱されない利益, いわば心の静穏の利益もまた, 不法行為法上, 被侵 害利益となり得るものと認めてよい」と述べてい る。また, 同様に最高裁は,「個人が他者から自己 の欲しない刺激によって心の静穏を乱されない利益 を有しており，これを広い意味でのプライバシーと 呼ぶことができる」としている。

Googleストリートビューの法的問題は，プライバ シーの侵害だけではない。ストリートビューと個人 情報の保護に関する法律（個人情報保護法）との関 わりについて, 直ちに同法違反といえる状況ではな いが，個人の顔や表札等が明瞭に判断できる画像に ついて，これが意図的に取得され，かつ恒常的にイ ンターネットで公開されており，本人や知人に識別 される場合，これが個人情報保護法第2条第1項で定 義する個人情報に該当するのではないかという疑念 は否定できない。

すなわち，これらの画像が，「生存する個人に関 する情報であって，当該情報に含まれる氏名，生年 月日その他の記述等により特定の個人を識別するこ とができるもの（他の情報と容易に照合することが でき，それにより特定の個人を識別することができ ることとなるものを含む)」に該当するかどうかが 問われることになろう。

\section{3. フェアユースの法理}

検索サービス事業を，法的に米国で支えているの
が米国著作権法 (Copyright Law of the United States) のフェアユース (fair use) (公正使用) の法理である。 この法理は, わが国著作権法にはない。つまり, 用 途は限定せず，その使用目的がフェアユースであれ ば著作権侵害とはならないという考え方である。検 索サービス事業について, 最も重要な米国の法理の ひとつであるので，簡単に紹介しておこう。

米国著作権法は, 著作者が自己の著作物に対して, 複製, 二次的著作物作成, 公衆への頒布, 公の実演, 公の展示，録音物のデジタル送信による公の実演を 行う権利を付与している（17 U.S.C. §106）が，一 定の場合，例外として著作物の複製を認めている。

フェアユースについて, 米国著作権法は, 「同法 第106条（著作権のある著作物に対する排他的権利） および同法第106A条（一定の著作者の氏名表示お よび同一性保持の権利）の規定にかかわらず，批評， 解説, 二ュース報道, 教授（教室における複数のコ ピーを作成する行為を含む), 研究または調査等を 目的とする著作権のある著作物のフェアユース（コ ピーまたはレコードへの複製その他第106条に定め る手段による使用を含む）は，著作権の侵害とはな らない」と規定している (17 U.S.C. § 107)。

また, 同法は,「著作物の使用がフェアユースと なるか否かを判断する場合に考慮すべき要素は, 以 下のものを含む」としており, 次の4項目を挙げて いる。すなわち，(1)使用の目的および性質（使用が 商業性を有するかまたは非営利的教育目的を含む), (2)著作権のある著作物の性質, (3)著作権のある著作 物全体との関連における使用された部分の量および 実質性，(4)著作権のある著作物の潜在的市場または 価值に対する使用の影響，である5)。

つまり, これらのすべての要素を考慮してフェア ユースが認定された場合, 著作物を著作権者の許諾 なく複製しても違法とはされない。

近時, 一般に, Googleの検索サービスは, 判例法上, 米国著作権法のフェアユースに該当し合法と認めら れているケースが多いが, Googleの検索エンジンが 
フェアユースに該当するか否かについて過去に争わ れたいくつものケースがある。次に, 若干, 代表的 な裁判例を紹介しよう。

\section{4. 過去の重要判例}

\section{1 テキスト情報に関する判例}

\subsubsection{Ticketmaster事件（2000年）}

米国でも，比較的初期の段階で，Webサイト上の リンクに関して著作権法違反になるかどうかが争わ れた有名な事件がある。これは，一般にTicketmaster 事件と呼ばれているものである6)。

裁判所は, Tickets.com社の著作権侵害について, 公に利用可能なWebページから基本的な事実を利用 することは，表現などの複製の事実がない限り著作 権侵害にはならない旨判示した。また，不正競争に ついても, ディープリンクの行為そのものは, 必ず しも不正競争には該当しない旨判示した。

この事件はリンクについて，その後の裁判例の先 例となった事件であり，インターネットのリンク行 為を合法と認めた判決である。

\subsubsection{Newborn事件（2005年）}

著作者の許諾を得ずにリンクを張り利用者に提供 することは，著作権の直接侵害には当たらないが寄 与侵害にあたるのではないか，として訴訟になった のがNewborn事件である7)。

寄与侵害の成立要件は，(1)第三者による直接侵害 が存在すること，(2)被告が(1)について知っているこ と，(3)被告が侵害行為にかなり加担していること， の3つである。また, (1)が認められるには, 原告は, （i）どの作品の著作権を侵害されているか，（ii） その作品の著作権を自分が保有しているか, (iii） 法律に従って著作権を登録したか，(iv）いつどの 行為で侵害されたのか，を立証しなければならな い。しかし, 原告のNewbornは, 著作物について米 国著作権局の登録番号を得ておらず，(1)を立証する
ことができなかった。そのため同地裁は寄与侵害を 否定した。

また, セーフハーバー (免責) 条項（17 U.S.C. § 512 （c）（1））を適用するためには，(1)侵害行為を知ら ない, (2)侵害行為から経済的利益を得ていない, (3) 侵害行為の通知があり次第, すみやかに侵害情報を 削除する,の3つの要件が必要となるが，同地裁は， 主張が不十分だとしてこれも否定した。

この事件は，著作物が米国著作権局の登録番号を 得ていないことが致命的となった。また，被告の サービスと侵害行為の関係を立証できなかったこと もあって，原告敗訴に終わった。

\subsubsection{Field事件（2006年）}

検索エンジンが保存したキャッシュへのリンク が，ホームページの著作権を侵害しているかどうか が争われた事件がField事件である8)。Fieldlは51の作 品を制作し，米国著作権局に登録した後，Webサイ トを作成して作品をアップロードしていた。Fieldは, ユーザがGoogleの検索エンジンでキャッシュリンク をクリックするたびに, FieldのWebページにある作 品のコピーを表示するのは, 著作権の直接侵害に当 たるとして裁判所に提訴した9)。

これに対し, Googlelよ, (1)Fieldはキャッシュペー ジの表示を黙示的に合意していた，(2Fieldは禁反言 の原則（一般に，前に言ったことを後で翻してはな らないという原則）により，侵害を主張できない (具体的に(1)を指す), (3)キャッシュページはフェア ユースに当たる, (4)キャッシュページはDMCA (Digital Millennium Copyright Act) のセーフハーバー条項に該 当する, と主張した。

同裁判所は, Webサイト運営者は, 検索エンジン に対してコンテンツを除去させることが可能である にもかかわらず, Fieldはそれをしなかったため默示 の合意があったとした。また, Googleは, Fieldの作 品除去要望については何も知らずに提訴されたの で, Fieldは侵害を主張できないとした。さらに, 同 
裁判所は,フェアユースの4要件を吟味した結果, 当該事案はフェアユースに該当するとし，Webペー ジのコピーは中間的かつ一時的蓄積に当たるとした。

なお，検索エンジンがWebページを複製して一時 的に保存（キャッシュ）することは，検索・表示さ れるWebサイトの著作権を侵害しないとした裁判例 にParker事件がある10)。

\section{2 画像情報に関する判例}

\subsubsection{Kelly事件（2003年）}

Googleに対する訴訟ではないが，サムネイル画像 に関する重要判例があるので紹介しておきたい。サ ムネイル画像 (thumbnail) とは, 親指 (thumb) の爪 (nail) 程度の大きさしかない画像の縮小版であり，検索結 果としてパソコン画面に表示される小さな画像のこ とである。1枚の画像は小さく, パソコン画面に何 十もの数を表示することができる。そのため, どの ような画像があるかをチェックするために用いるも のである。

画像の縮小版であるこのサムネイル画像の表示 が，著作権者の許諾を得ずに無断で複製したものと して著作権法違反で提訴したのがKelly事件である ${ }^{11)}$ 。

この結果, サムネイル画像はフェアユースとして 認められ，著作権法違反には当たらないとされた。 この判例の意義は大きい。なぜなら次世代の検索工 ンジンは，画像検索が中心的な機能になるからであ る。現時点でのネット検索では，入力するキーワー ドが文字列であるため, 基本的には, 文字列の埋め 込まれていない画像は検索結果として表示されにく い。しかし，わが国の情報大航海プロジェクトでも 研究されているように，たとえ文字列を入力したと しても，次世代の検索エンジンでは，画像が検索結 果として表示されることになる。その場合に, サム ネイル画像は検索結果表示としては欠かせないもの になり得るからである。

\subsubsection{Perfect 10事件（2006年）}

サムネイル画像が問題となったもうひとつの重要

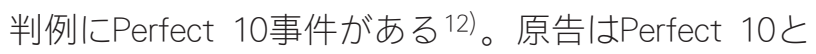
いう画像を提供する業者であり, 自社のサイトに画 像を掲載しそれを販売していた。このサイトは会員 制をとっていたので, Googleでは画像検索がされな かったが，第三者が入手した画像が原因となった事 件である。

これらの判決では寄与侵害の問題は残るものの, Kelly事件, Perfect 10事件とも, サムネイル画像使用 をフェアユースとして認めたわけであり, 検索エン ジンの画像検索結果を容易に表示する方法としてサ ムネイル画像使用を容認する結果をもたらした。

しかし, サムネイル画像が検索結果の表示として の機能のみを有するものであれば，これら判決は首 肯できるが, サムネイル画像から容易にフルサイズ 画像に変換できるものであれば，異なる判決が出さ れたかもしれない。つまり, 画像をその大きさによ りサムネイル画像かフルサイズ画像かを判断するこ とは極めて乱暴であり, 検索結果としての具体的な サムネイル画像の定義を行うべきであろう。

\section{5. 結びにかえて}

Googleの提供するサービスの最新動向およびフェ アユースの法理, 代表的判例を簡単に紹介したが, Googleを巡る訴訟は, 初期のリンク・フレームの問 題から画像情報, サムネイル画像などに展開し, 今 やプライバシーや個人情報に関する問題, 集団訴訟 に関する問題など多岐にわたってきている。しか し，これらGoogleの提供するサービスの共通点は， Googleがそのビジネス戦略にオプト・アウト方式を 採用している点にある。

これは, 明らかにGoogleが訴訟リスクを取ること を前提に，これらビジネス分野での主導権を握ろう としている表れであろう。その理由として, Google がもともと技術主導のベンチャー企業であり, 訴訟 
リスクを覚悟の上でネットビジネスの分野で果敢に 挑戦してきた社風であると考えることもできる。

例えば，著作権のある書籍をGoogleブック検索の 対象とする場合は，事前に著作権者の許諾を受ける 必要がある(オプト・イン方式)。ところが，この 方法では著作権者からいちいち許諾を取ることに多 大な労力と時間がかかる。Googleブック検索では, パブリック・ドメイン，保護期間切れ，孤児作品以 外の書籍の場合，抜粋（ス二ペット）のみが表示 されるが，この場合は，事前に著作権処理をせず， 著作権者がそれを望まない場合には，著作権者が Googleに通知することにより，抜粋をしない方法を 採っている（オプト・アウト方式）。

Google以外でも同じような書籍検索のプロジェク トがあるが，これらはオプト・イン方式を採用して いる。Googleが訴訟リスクを取ってまで，オプト・ アウト方式を採用する理由は, Googleの検索サービ スの巨大な市場の早期獲得のためだと考えられる。

オプト・アウト方式を合法的に認めているものに 個人情報保護法第23条があるが，オプト・アウト方 式は，法によって合法的に明確に認められている場 合，または利用者が事前に承諾をしている場合を除 き，安易に採用するものではないであろう。なぜな ら, Googleストリートビューの画像削除依頼のよう に，利用者に多大な時間と労力の負担をかける可能 性が大きいからである。

また，Googleのように，訴訟リスクを取りながら 大胆にビジネスを展開するやり方は，Googleのよう な資金に余裕のある企業にとっては, 懲罰的損害賠 償や差止請求がない限り, ビジネス戦略としては成 功を収める可能性が高いと言える。しかし, 一方で, 法令遵守を厳に考え，新たなビジネスに挑戦しない 企業もあるのも事実である。つまり，ルールとして の法を考えた場合，ルールを守る者亡守らない者の フェアネス (公平性) が保たれるかが，今後の問題 となり得るのではないだろうか。なぜなら，ビジネ スの世界でも機会均等が原則であり, ルールを冕脱
したビジネスは，ビジネス上の法秩序の破壊につな がる恐れがないとは言えないからである。

また，米国のGoogleブック検索の集団訴訟の和解 の影響がわが国の権利者にも及ぶことになるが，そ の直接の原因はベルヌ条約ではなく，米国の集団訴 訟という法システムに基づくものである。公害問題 や製造物責任の集団訴訟の場合は，その利害関係が 明確であり，その範囲も大規模なものでも数万人で ある。しかし, 今回のGoogleブック検索の利害関係 は，公害問題や製造物責任のように単純ではない。 またその規模は全世界に及び，数百万人から数千万 人もの関係者にも及ぶことが予想される。

なお，権利者の特定と分配のために「版権レジス トリ」と呼ばれる非営利法人が設立されるが，この 非営利法人に多大な権限を与えることになる反面, 果たしてどこまで公正妥当に膨大な処理をこなすか は誰にもわからない。それを担保する仕組みを作る 必要があるのではないだろうか。

情報の流通が, 水道, 電気, ガスのような生活上 のインフラとしての性格を帯び, 公共性および公益 性が求められるようになってきた現在，その情報の 取り扱いには一定のルールと歯止めが必要ではなか ろうか。Googleのような一民間企業が，世界中のあ らゆる情報を独占的に収集·統合し，その活用によっ て利益を上げるのであれば，企業倫理の問題として 各企業にその判断を委ねるのではなく, その公共性, 公益性および社会的影響を考慮し，これら情報収集 ビジネスに一定の法的な枠組みを備える必要がある と思われる。

法が技術の後追いをする傾向があるなかで，技術 とその活用を予測しながら立法政策を練ることは極 めて難しい作業ではあるが, 現代社会における情報 の持つ意義を考えるならば，真剣に取り組む時期が 来ているのではないだろうか。本来, 民間企業が経 済活動を続けるための情報収集管理システムが，別 の意味における人間行動の監視システムとしても有効 であることをわれわれは忘れてはならないであろう。 


\section{参考文献}

1）高田寛. “Web2.0サイバースペースにおける法規制についての一考察”. 産業能率大学紀要. 2008, vol. 28, no. 2, p. 1.

2）“Googleブック検索和解契約”. Googleブック検索. http://books.google.com/intl/ja/googlebooks/ agreement/, (参照2009-05-30).

3) The Author's Guild v. Google Inc., No.05-8136 (S.D.N.Y., 2005).

4）高田寛. “検索エンジンの社会的影響と法的問題一Googleを例に一”。産業能率大学紀要. 2008, vol. 29, no. 1, p. 55.

5）城所岩生. 検索エンジンと米国著作権法 [上]. 国際商事法務. 2007, vol. 35, no. 5, p. 601.

6) Ticketmaster Corp. v. Tickets. com Inc., 54 U.S.P.Q.2d 1344 (C.D.Cal., 2000).

7) Newborn v. Yahoo! Inc., 391 F.Supp.2d 181 (D.D.C., 2005).

8) Field v. Google Inc., 412 F.Supp.2d 1106 (D.Nev., 2006).

9) 田村善之. 検索サイトをめぐる著作権法上の諸問題(1)一寄与侵害, 間接侵害, フェア·ユース, 引用等. 知的財産法政策学研究. 2007, vol. 16, p. 74-77.

10) Parker v. Google Inc., 422 F.Supp.2d 429 (E.D.Pa., 2006).

11) Kelly v. Arriba Soft Corp., 336 F.3d 811 (9th Cir., 2003).

12) Perfect 10 Inc. v. Google Inc., 416 F. Supp.2d 828 (C.D.Cal., 2006).

\section{編集部注：}

米国判例の読み方は以下の通り。

原告 v. 被告, 巻 判例集略称ページ (裁判所略称, 判決年)

詳しくは以下の書籍を参照のこと。

Harvard Law Review. The Bluebook: A Uniform System of Citation. 16th ed., Harvard Law Review Association, 1997, 365p. http://www.legalbluebook.com/, (accessed 2009-06-19).

\section{Author Abstract}

Recently, besides a past search engine, Google provides new services, such as of Google Book Search and the Google Street View, etc., and begins to have a big influence socially. However, there are a lot of legally unsettled parts in these new services. In this paper, I present the overview of recent Google services, typical important cases of web search engines and potential juridical problems of search engine services in the future.

\section{Key words}

web search service, search engine, Google Book Search, Google Street View, fair use, orphan works, class action, opt-out 